the force exerted by the revolving balls tending to raise the ends of the spring, will be applied, as it were, through a lever of which the fulcrum is at a point near the centre, while as the spring rises, this fulcrum gradually approaches the farther end of the lever giving an increased leverage as the rigidity of the spring increases.

It will be evident that by transmitting the force imparted to the sleeve by the action of the revolving weights, to the spring through the medium of a knee-joint; the increasing rigidity of the spring as its opposite ends are raised, is counteracted by an increase in the force applied to raise the said ends, and consequently, that the action of the governor is uniform throughout.

For the Journal of the Franklin Institute.

\title{
Description and Trial Trip of the Steamship Continental.
}

In the early part of the year 1862, the Ocean Steam Navigation Company asked proposals of the marine engine builders of this city for a propeller engine, competent to develop the same power as that of their paddle wheel steamship, Keystone State, whose cylinder has a bore of 80 inches, and length for 8 feet stroke; number of revolutions, 15 per minute with a steam pressure of $22 \mathrm{lbs}$, cut-off at onehalf the stroke.

At the same time, proposals were given for the hull, to be built from the designs of Mr. J. W. Griffth, naval architect.

The contracts were awarded to Messrs. Merrick \& Sons for the engine, and to Mr. J. W. Lynn for the hull. The following are the principal dimensions of both:-

Hull.--Length for tonnage, $238 \mathrm{ft} .6$ ins. Do. for deep load-water line, $221 \mathrm{ft}$. 7 ins. Breadth of beam at midship section, $38 \mathrm{ft}$. Depth of hold, $16 \mathrm{ft}$. Length of engine and boiler space, $33 \mathrm{ft}$. Isength of shaft, forward of stern post, $76 \mathrm{ft}$. Draft of water at deep load line, $12 \mathrm{ft}$. Draft of water at below pressure and revolutions, $11 \mathrm{ft}$. forward, $11 \mathrm{ft}$. 6 ins. aft. Area of immersed section at $12 \mathrm{ft}$. draft, 390 sq. $\mathrm{ft}$. Masts and rig, schooner.

Engine.-Diameter of cylinder, 50 ins. Length of stroke, $3 \mathrm{ft.} 9$ ins. Maximum pressure of steam in pounds, $35 \mathrm{lbs}$. Cut off, $\frac{2}{3}$ stroke. Maximum revolutions per minute, 56.

Boilers.--Two. Length of boilers, $12 \mathrm{ft}$. Breadth or face, 20 feet. Number of furnaces in each, 6. Breadth of furnaces, $2 \mathrm{ft} .9$ ins. Length of grate bars, $6 \mathrm{ft} .8$ ins. Number of flues or tubes in each, 336. External diameter of flues or tubes, 3 ins. Length of flues or tubes, $7 \mathrm{ft}$. 6 ins. Heating surface, total, 4860 sq. $\mathrm{ft}$. Diameter of smokepipe, $6 \mathrm{ft}$. Height, do. $40 \mathrm{ft}$. Description of coal, anthracite. Draft, natural. Consumption of coal per hour, $1 \frac{1}{3}$ tons.

Propeller.-True screw. Diameter, 12 ft. 6 ins. Length of Blades, fore and aft, $2 \mathrm{ft}$. 6 ins. Pitch, $24 \mathrm{ft}$. Number of blates, 4. Average revolutions per minute, 52.:

Remarks.-Fitted with a surface condenser; also, with J. V. Merrick's patent double ported balanced slide valve, and with a small slide valve for warming up and starting the engine. Independent fire and bilge pump. Independent engines for hoisting cargo, and also the ashes from the fire room upon a labor saving plan devised by $\mathrm{Mr}$. 
Alexander Heron. Agent of the Company. Mr. Heron also arranged coal bunks from the upper deck downwarls so as to cause nearly their entire contents to run towards the bunker doors by gravity, thus dispensing with the coal passers. Fifty tons of coal are carried in bunks built over the boilers, intended as a reserve to be used in an emergency.

The following is an account of her first performanee, which touk place November 26 th, 1862.

Trial Trip of Steamer Contrnsutal, November 26th, 1862.

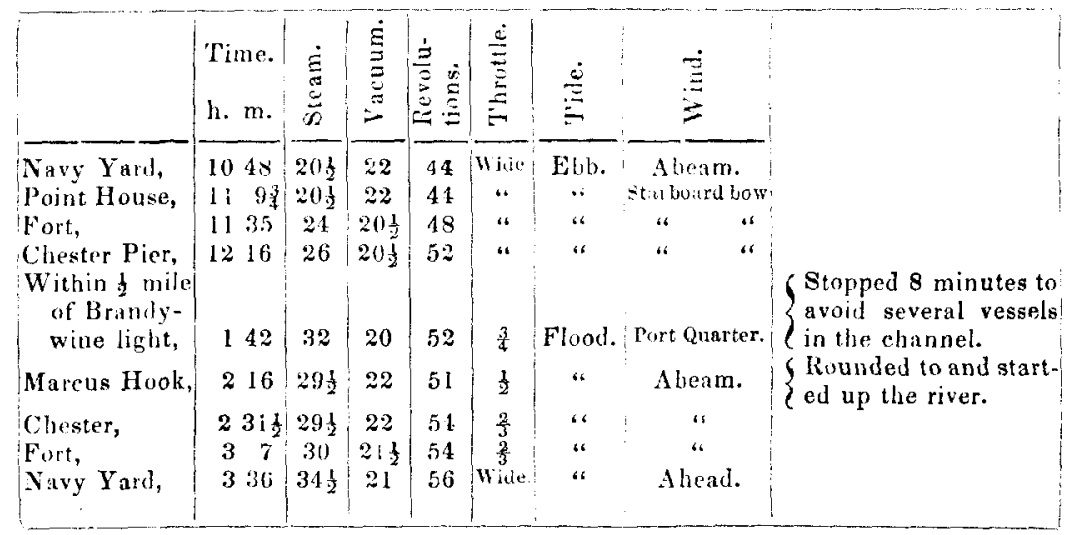

By taking the distance from Marcus Hook to the Navy Yard, the longest distance run between measured points made without a stop, at 201 miles, and allowing $2 \frac{1}{2}$ miles por hour for the tide and dividing by the time, we will have speed of ship through the water in miles per lour, thus : $-\frac{20 \cdot 25-2 \cdot 5}{3 \cdot 36-2 \cdot 16}=13 \cdot 3125$ miles.

The wind, being unfavorable, retarded the ship somewhat, as she was very high out of the water; and the speed in calm weather through the water would most likely be about 133 miles, and might exceed that if she were loaded so as to immerse the whole of the propeller, which, it will be seen, was fully 1 its diameter above the water. The trial was satisfactory to all concerned; the time occupied in running between certain points was alnost identical with that of the Keystone State on her trial, as:-from Marcus Hook to Chester, 30 seconds less; and, from Chestor to Navy Tard one minute more. The two hulls had about the same immersed scction which shows that the engine of the Continental came up to the regnirements of the contract.

The balanced slide valve worked admirably; one man being able to shift with ease, the slot link from ahead to backing point by means of a 34-inch hand wheel upon the same shaft with a 4 -inch pinion, working into a rack attached to the link. The valve is 34 ins. wide by 38 ins. long. Steam of the before mentioned tension when pressing upon an unbalanced valve of this size exerts a force $=34 \times 38 \times 341 \mathrm{lbs}$. $=44574 \mathrm{lbs}$. and as friction of cast iron upon cast iron when lubricated 
is about ${ }_{1}^{1}$ th total weight, or pressure on surfaces, we have $4457 \mathrm{lbs}$. required to move the valve. The entire motion of the valve is 7 ins. and the power required to work it (still supposing it to be unbalanced) would be at 56 revolutions of engine $\frac{4457 \times \frac{7}{2} \times 2}{33000}=8.82$ horses.

An examination of the valve after two voyages had been made from New York to New Orleans and back, and one voyage from Philadelphia to Now York and back showed that nothing better, as a balanced slide valve need be desired, the rubbing surfaces being polished like mirrors.

Messrs. Merrick \& Sons applied this balanced valve to the engines of U.S. Steamer New Ironsides, and are about to place it on those of U. S. Steamer Yantic and Ram Ionawanda now building at their works. J.

\section{For the Journal of the Franklin Institute. \\ Particulars of the Ship Cremorne.}

Hnll built by Maxson, Fish \& Co., Mystic, Conn. Commander, Capt. Isaac D. Gates. Intended service, California and East India Trade. Owners, Lawrence, Giles \& Co., New York.

Hull.-Length over all, $200 \mathrm{ft}$. Breadth of beam, $39 \mathrm{ft}$. Depth of hold, $14 \mathrm{ft}$. Do. between decks, $9 \mathrm{ft}$. Half poop, including mainmast, $4 \mathrm{f} \mathrm{ft}$. Keel, 15 by 24 ins. Frames -molded, 17 ins. Bilge strakes, 12 ins., diminishing to 8 ins. Lower deck bearn, 15 by 15 ins. Main deck, do., 14 by 12 ins. Garboard strake, 6 ins. Bottom plankinr, 4 ins. Wales, 5 ins. Tonnage, 1413 tuns.

Masts, \&c.-Foremast, $74 \mathrm{ft}$. Diameter of do., 31 ins. Mainmast, $77 \mathrm{ft}$. Diameter of do., 32 ins. Mizzen-mast, $70 \mathrm{ft}$. Diameter of $30 ., 25$ ins. Topmasts, $46 \mathrm{ft}$. Lower Yards, $72 \mathrm{ft}$. Lower Topsail Yards, $63 \mathrm{ft}$. Upper do., $50 \mathrm{ft}$.

Remarks. - This vessel is well built, and in every respect thoroughly and heavily fastened with composition spikes, copper butt bolts, and treenails. Her keel is of white oak, also her keelsons of three thicknesses, all edge-bolted. Her frames are of white oak and white chestnut, very heavy; ceiling, whito oak, beams and deck frame, white chestnut, all full kneed with hacmetac and oak knees; clamps are edge-bolted; patent windlass. Has six hooks and pointers forward, and same number aft. Launched, March 19th, 1863.

B.

For the Journal of the Franklin Institute.

$$
\text { Speed of Ships. }
$$

The Barque Nelly of New Castle, Del., 506 tons burthen, belonging to Mr. J. C. Brooks of that place, recertly made the passage from New York to Sligo in 18 days. When it is considered she contended with easterly winds, and the vessel was deeply laden with grain, this passage is extraordinary. It has rarely been equalled, much less surpassed. 